\title{
Local Extrahepatic Expression of Complement Genes C3, Factor B, C2, and C4 Is Increased in Murine Lupus Nephritis
}

\author{
Justen Passwell, George F. Schreiner, ${ }^{*}$ Masaru Nonaka, Horst U. Beuscher, and Harvey R. Colten \\ Edward Mallinckrodt Department of Pediatrics, and ${ }^{*}$ Departments of Internal Medicine and Pathology, Washington University School \\ of Medicine, St. Louis, Missouri 63110
}

\begin{abstract}
Systemic lupus erythematosus (SLE) is associated with the presence of complement proteins and immune complexes in affected organs. Since complement proteins are synthesized in hepatic and extrahepatic sites, we studied a murine model of SLE to ascertain the relative importance of local and humoral (liver) synthesis of complement. C3, C4, and C2 mRNA increase in kidney coincident with the development of nephritis in the MRL lpr/lpr mouse, a strain that spontaneously develops SLE. Two factor B messenger RNA transcripts are expressed in kidney and intestine; SLE nephritis is associated with decrease in the long factor $B$ mRNA and increase in the short form. Increased local synthesis of $\mathrm{C} 3$ and $\mathrm{B}$ protein and a concomitant glomerular and renal interstitial macrophage infiltrate paralleled the increase in mRNA content in the (lpr/ lpr) mice. In addition to kidney, an increase in C3, C4, C2 and factor $B$ mRNA was noted in the lung, heart and intestine and to a lesser extent in liver of (lpr/lpr) in comparison to the MRL $(+/+)$ animals.

These results suggest that in SLE local expression of complement genes plays a role in the pathogenesis of chronic glomerulonephritis and in the autoimmune arteritis of other organs.
\end{abstract}

\section{Introduction}

The MRL-LP lpr/lpr inbred mouse strain consistently develops a spontaneous murine systemic lupus erythematous (SLE) ${ }^{1}$ syndrome with severe glomerulonephritis and evidence of arteritis in other organs. Lymph gland hyperplasia and arthritis are also common clinical features. Serologic studies show a progressive increase with age, of immunoglobulin concentrations, circulating immune complexes, anti-DNA and other autoantibodies, and a decrease in total serum complement hemolytic activity $(1,2)$.

Immune cell infiltration into affected organs is particularly prominent in this murine model of SLE. The expression of

Dr. Passwell was on sabbatical leave from the Sackter School of Medicine, Tel Aviv, Israel.

Address reprint requests to Dr. Colten, Department of Pediatrics, Washington University School of Medicine, 400 South Kingshighway, St. Louis, MO 63110.

Received for publication 8 February 1988 and in revised form 20 June 1988.

1. Abbreviations used in this paper: SLE, systemic lupus erythematosus.

J. Clin. Invest.

(c) The American Society for Clinical Investigation, Inc.

$0021-9738 / 88 / 11 / 1676 / 09 \$ 2.00$

Volume 82, November 1988, 1676-1684 autoimmunity is associated with the emergence of a lymphoid cell population of unusual phenotype $\left(\mathrm{Ly} 1^{+}-\right.$, dThy $-1^{+}$, ${\mathrm{L} 34^{-}}^{-}$(3). Abnormal immunoregulation by $\mathrm{T}$ cells is clearly implicated in the pathogenesis of the disease since depletion of $T$ cells by monoclonal anti-T cell antibody (4), thymectomy (5), allogeneic bone marrow transplantation (6), or treatment with cyclosporin (7) can prevent or ameliorate the systemic autoimmune disease.

In the MRL lpr/lplr mice, as in the human disease, deposits of immunoglobulin and complement components, particularly C3, are identified in the kidney with progression of disease. Activated complement proteins may cause tissue injury directly or recruit inflammatory effector cells (8).

There is increasing evidence that macrophages have an important role in the pathogenesis of glomerulonephritis. In rat and rabbit experimental models of glomerulonephritis and in the NZB model of murine lupus, mononuclear phagocytes are recruited into the glomerulus during the development of inflammation (9-11). The functional role of these cells may be regulation of local immune response (they express the Ia antigen and react with lymphocytes in a genetically restricted manner [12]), clearance of immune complexes (13), enhancement of tissue injury by release of products such as prostaglandins and leukotrienes (14) and coagulant factors (15), all of which have been identified in isolated glomerular cultures from rats with glomerulonephritis.

The complement proteins in serum are synthesized by hepatocytes but extrahepatic expression of these proteins in mononuclear phagocytes has been demonstrated as well (16). In several experimental models, hepatic and extrahepatic regulation of complement gene expression have been shown to be under independent control $(17,18)$. To ascertain whether local expression of complement proteins may also play a role in the immunopathology of lupus nephritis, we examined the concentration of mRNA for C3, factor $\mathrm{B}, \mathrm{C} 4$ and $\mathrm{C} 2$ in the kidney and other organs of the MRL lpr/lpr and the congenic MRL $+/+$ mouse strains at timed intervals. A marked increase in mRNA for these complement proteins in the lpr/lpr kidney and in other organs affected by the autoimmune disease was observed concomitant with the development of SLE. The increased mRNA content is reflected in increased synthesis of complement in the nephritic kidney. Finally, using the F4/80 monoclonal antibody that identifies a specific mouse macrophage antigen (19), a glomerular and interstitial macrophage infiltrate correlated with progression of the kidney disease.

\section{Methods}

Mice. MRL (lpr/lpr) and MRL (+/+) male mice were purchased from the Jackson Laboratory (Bar Harbor, Maine). They were maintained on a regular diet and given water ad lib. Urine for protein analysis was collected from groups of mice in metabolic cages. At four time points, 
i.e., $6,12,18$, and $22 \mathrm{wk}$, mice were killed by cervical dislocation and bled by cardiac puncture, and the liver, kidneys, spleen, lungs, intestine, and heart were rapidly removed. Small slices of liver and kidney were obtained and stored in 10\% formalin for histology and quick frozen in liquid nitrogen for immunohistology. The remainder of the organs were frozen in liquid nitrogen and stored at $-70^{\circ} \mathrm{C}$ until processed for isolation of total RNA. Blood was collected into tubes with EDTA and kept on ice, and the separated plasma was stored at $-70^{\circ} \mathrm{C}$ until analyzed for $\mathrm{C} 3$, anti-DNA antibody, and creatinine concentrations. Urine protein content was determined by a quantitative sulfosalicylic method (20). C3 concentration in the plasma was quantitated by immunodiffusion using a rabbit anti-mouse $\mathrm{C} 3$ antibody kindly provided by Dr. Natsuume-Sakai (Cancer Research Institute, Kanazawa University, Japan). Plasma from 8-wk-old Balb/c mice (C3 50 $\mathrm{mg} / \mathrm{dl}$ ) was used as standard. Plasma creatinine was measured by a routine method using an autoanalyzer. Kidney and liver sections were embedded in paraffin, stained with hematoxylin and eosin and periodic acid-Schiff and reviewed in a "blinded" fashion.

To permit greater specificity in scoring progression of renal disease, histology was evaluated for the severity of changes in three categories: (a) acute glomerulonephritis (GN), (b) glomerulosclerosis (GS), and (c) interstitial inflammation (IN) according to the following scoring scale:

\begin{tabular}{|c|c|c|c|c|}
\hline \multicolumn{2}{|c|}{ Score: +} & \multirow{2}{*}{$\begin{array}{l}c \text { c+ } \\
\begin{array}{l}\text { Diffuse mes- } \\
\text { angiopro- } \\
\text { liferative } \\
\text { disease }\end{array}\end{array}$} & \multirow{2}{*}{ 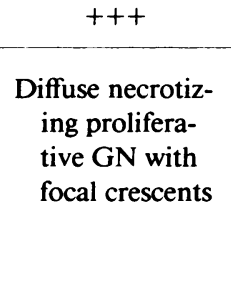 } & \multirow{2}{*}{ 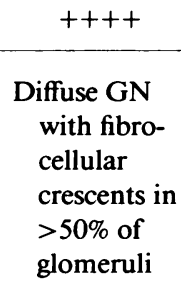 } \\
\hline GN & $\begin{array}{l}\text { Focal segmen- } \\
\text { tal mesan- } \\
\text { gioprolifer- } \\
\text { ative } \\
\text { changes }\end{array}$ & & & \\
\hline GS & $\begin{array}{c}\text { Focal segmen- } \\
\text { tal sclerosis }\end{array}$ & $\begin{array}{l}\text { Focal glomer- } \\
\text { ular hya- } \\
\text { linosis }\end{array}$ & $\begin{array}{l}\text { Diffuse, seg- } \\
\text { mental glo- } \\
\text { meruloscler- } \\
\text { osis }\end{array}$ & $\begin{array}{c}\text { Diffuse glo- } \\
\text { merular } \\
\text { hyalinosis }\end{array}$ \\
\hline IN & $\begin{array}{l}\text { Patchy non- } \\
\text { necrotizing } \\
\text { mononu- } \\
\text { clear cell } \\
\text { infiltrate }\end{array}$ & $\begin{array}{l}\text { Diffuse inter- } \\
\text { stitial infil- } \\
\text { trate }\end{array}$ & $\begin{array}{l}\text { Necrotizing in- } \\
\text { terstitial infil- } \\
\text { trates with in- } \\
\text { terstitial } \\
\text { edema and } \\
\text { focal tubular } \\
\text { atrophy }\end{array}$ & $\begin{array}{l}\text { Diffuse inter- } \\
\text { stitial fi- } \\
\text { brosis and } \\
\text { tubular at- } \\
\text { rophy }\end{array}$ \\
\hline
\end{tabular}

The F4/80 hybridoma (kindly provided by Dr. Howard Gray, University of Colorado, Denver) was cultured in RPMI $1640+10 \%$ heatinactivated fetal calf serum. The monoclonal antibody was precipitated from the culture supernatant by $50 \%$ ammonium sulphate and dialyzed for $48 \mathrm{~h}$ against PBS.

Immunoperoxidase labeling of renal tissue. Frozen sections $(6 \mu \mathrm{m})$ of kidneys harvested from control and experimental animals were fixed in chilled $\left(4^{\circ} \mathrm{C}\right)$ acetone for $10 \mathrm{~min}$ and air-dried. Endogenous peroxidase activity was inhibited by immersion for $10 \mathrm{~min}$ in a solution consisting of 40 parts methanol, 9 parts $\mathrm{H}_{2} \mathrm{O}$, and 1 part $\mathrm{H}_{2} \mathrm{O}_{2}$ $(30 \%)$. Endogenous biotin activity was inhibited by sequential $30-\mathrm{min}$ exposures to avidin $\mathrm{D}$ and biotin blocking solutions (Vector Laboratories, Burlingame, $C A)$. The sections were then placed in rabbit serum blocking solution (Zymed Laboratories, San Francisco, CA), followed by $\mathrm{F} 4 / 80$ antibody (diluted $1: 10$ in PBS containing $3.5 \%$ bovine serum albumin) for $30 \mathrm{~min}$. After washing, biotinylated rabbit anti-rat IgG (Vector Laboratories) affinity purified and adsorbed against mouse IgG, was added for $15 \mathrm{~min}$. After washing, the slides were sequentially exposed to streptavidin-peroxidase followed by aminoethyl carbazole and hydrogen peroxide, as supplied by Zymed Laboratories. The sections were counterstained with hematoxylin and mounted under coverslips.
Cells were scored positive for expression of the F4/80 antigen if they demonstrated a rim pattern of membrane labeling with the chromagen. Interstitial cells are expressed as positive cells per 100 tubule cells, which were uniformly negative, in order to minimize sampling error. 15 high-power fields were read per section. All glomeruli on a section (10-20 glomeruli per section) were scored for positive labeled cells and the results calculated on a per glomerular basis.

$m R N A$ isolation. At early time points (6 and $12 \mathrm{wk}$ ) two animals and at 18 and 22 wk four animals from each strain were used for mRNA studies. Organs were pulverized in liquid nitrogen with a mortar and pestle and lysed using $4 \mathrm{M}$ guanidium thiocyanate as described previously (21). RNA was separated from the lysates by ultracentrifugation $\left(35,000 \mathrm{rpm}\right.$ at $20^{\circ} \mathrm{C}$ for at least $12 \mathrm{~h}$ using a SW50.1 rotor, Beckman Instruments, Inc., Fullerton, CA) through a $5.7 \mathrm{M}$ cesium chloride gradient. The RNA pellet was washed in $70 \%$ ethanol, dissolved in water, reprecipitated in sodium acetate and ethanol, and redissolved in water. RNA content was determined by measurement of absorption at $260 \mathrm{~nm}$.

Northern blot analysis. RNA was separated by $1 \%$ agarose formaldehyde gel electrophoresis run for at least $12 \mathrm{~h}$, then transferred to nylon membranes (Hybond-N, Amersham Corp., Arlington Heights, IL) by blotting and fixed by exposure to an ultraviolet light source for 5 min. cDNA probes were labeled with $\left[{ }^{32} \mathrm{P}\right] \mathrm{dCTP}$ by nick translation and Northern blot hybridization was performed as described previously (22). Prehybridization and hybridization with specific RNA probes (see below) were done at $55-60^{\circ} \mathrm{C}$ in $50 \%$ formamide, $50 \mathrm{mM}$ sodium phosphate $\mathrm{pH} 6.5,0.8 \% \mathrm{NaCl}, 1 \mathrm{mM}$ EDTA, $0.5 \%$ Denhardt's solution, $500 \mu \mathrm{g} / \mathrm{ml}$ denatured salmon sperm DNA, and $500 \mu \mathrm{g} / \mathrm{ml}$ yeast RNA (Sigma Chemical Co., St. Louis, MO). Filters were washed at $65^{\circ} \mathrm{C}$ in $50 \mathrm{mM} \mathrm{NaCl}, 20 \mathrm{mM}$ sodium phosphate $\mathrm{pH} 6.5,1 \mathrm{mM}$ EDTA, and $0.1 \%$ SDS. Semiquantitative analysis of the amount of increase in mRNA was quantitated by laser densitometry of the autoradiographs.

Probes. For C2 mRNA the 800 bp Pst I fragment of the pC2M mouse cDNA clone was used (23). The $\mathrm{C} 4$ probe, a $1.4-\mathrm{kb}$ fragment of the clone pFC4/5.4 (24), and a chicken $\alpha$-actin cDNA (25), which hybridizes to $\beta$ and $\gamma$ actin, were used. Synthetic oligomers of mouse C4 (CCTGCAGCATGTTGTGGTTG) and Slp (AATTCACCATGTCCCGGACC) were kinase labeled with $\left[{ }^{32} \mathrm{P}\right] \mathrm{ATP}$. A 1.3-kb Pst I fragment from mouse factor B cDNA clone pBmB2 (26) was subcloned into a $\mathrm{PGEM}_{4}$ standard cloning vector and transformed into Escherichia coli. Transcription of the RNA probe was achieved by linearizing the vector with Sma I and labeling with $\left[{ }^{32}\right.$ P]UTP following the protocol of the supplier (Promega, Madison, WI). A mouse C3 cDNA clone (kindly provided by Dr. M. Takahashi, Kanazawa, Japan) containing a $2.7-\mathrm{kb}$ insert was digested with Pst I. Five distinct bands were identified. An 800-bp fragment was subcloned into $\mathrm{PGEM}_{\mathbf{4}}$ and used for transcription of labeled RNA as described above.

Biosynthesis, immunoprecipitation, and SDS PAGE. Kidneys from 6- and 18-wk-old MRL (+/+) and MRL (lpr/lpr) mice were harvested into cold PBS with $1.5 \mathrm{mM} \mathrm{KCl}$ and heparin $(10 \mathrm{U} / \mathrm{ml})$ and kept on ice. Coronal kidney slices approximately $0.2 \times 1 \mathrm{~cm}$ were cut with a razor blade and washed twice and incubated for $20 \mathrm{~min}$ at $37^{\circ} \mathrm{C}$ in methionine-free DME (Gibco, Grand Island, NY) tissue culture media. The tissue slices were transferred to the wells in separate $16-\mathrm{mm}$ tissue culture plates, medium was removed, and $0.5 \mathrm{ml}$ of medium containing $\left[{ }^{35} \mathrm{~S}\right]$ methionine $(0.5 \mathrm{mCi} / \mathrm{ml}$, sp act $\sim 1,000 \mathrm{Ci} / \mathrm{mmol}$; Amersham Corp.) was added. After $1 \mathrm{~h}$ the kidney slices were harvested in lysis buffer (10 mM EDTA, $1 \%$ Triton X100, $0.5 \%$ deoxycho-

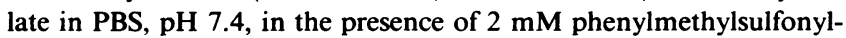
fluoride and $250 \mu \mathrm{g} / \mathrm{ml}$ soybean trypsin inhibitor [Sigma Chemical Co.]) and frozen at $-70^{\circ} \mathrm{C}$. Intracellular lysates of kidney were obtained by repeated freeze thawing and vigorous vortexing of the organ slices. Total protein synthesis was determined by TCA precipitation of aliquots of the intracellular lysates and extracellular media. Samples were precleared with formalin-fixed Staphylococcus aureus and successive immunoprecipitations with anti-mouse C3 (Cappel Laboratories, Malvern, PA) and a goat anti-human factor B cross-reactive with the 
Table I. Urine and Plasma Findings in the MRL Strains with Increasing Age

\begin{tabular}{|c|c|c|c|c|c|c|c|c|c|}
\hline & \multirow[b]{2}{*}{ Age $(w k)$} & \multicolumn{4}{|c|}{$\operatorname{MRL}(+/+)$} & \multicolumn{4}{|c|}{ MRL (lpr/lpr) } \\
\hline & & 6 & 12 & 18 & 22 & 6 & 12 & 18 & 22 \\
\hline Urine protein $(\mathrm{mg} / \mathrm{ml})$ & & 0.85 & 1.73 & 3.15 & 1.77 & 4.87 & 6.39 & 9.67 & 8.17 \\
\hline Plasma creatinine* $(m g / m l)$ & & 0.2 & 0.3 & 0.2 & 0.2 & 0.2 & 0.2 & 0.2 & 0.4 \\
\hline Plasma C3 $3^{\ddagger}(m g / d l)$ & & $70 \pm 5$ & $54 \pm 18$ & $80 \pm 7$ & $106 \pm 15$ & $61 \pm 6$ & $48 \pm 6$ & $77 \pm 3$ & $76 \pm 4$ \\
\hline Anti-DNA antibody ${ }^{\S}(1 /$ titer $)$ & & neg & 40 & 40 & 40 & 20 & 320 & 10,240 & 5,120 \\
\hline
\end{tabular}

* Average of two to three individual mice at each time point. ${ }^{\ddagger}$ Average of three to seven individual mice at each time point. ${ }^{\S}$ Samples from one mouse at each time point.

mouse antigen (Atlantic Antibodies, Scarsborough, ME) were done exactly as described previously (17). The immune complexes were precipitated with formalin-fixed Staphylococcus aureus (IgSorb Enzyme Center, Malden, MA), washed extensively, and subjected to SDS-PAGE under reducing conditions ( $5 \% \beta$-mercaptoethanol). The gels were treated with $\mathrm{En}^{3}$ hance, dried under vacuum after which autoradiography was performed.

\section{Results}

Clinical findings. By 18 wk of age the mice of the lpr/lpr strain manifested ulcerated skin lesions, lymphadenopathy, and lacked their normal coat lustre. There was a progressive increase in proteinuria (Table I). Plasma C3 concentrations, which were higher than that of the BALB/c mouse strain, did not decrease with the development of renal disease, but were less than the $\mathrm{C} 3$ levels in the $+/+$ strain at 22 wk of age. There was a marked progressive elevation of anti-DNA antibodies in plasma of the lpr/lpr strain with only a modest increase in the $+/+$ strain. The creatinine concentration was slightly elevated only at the last time point ( $22 \mathrm{wk}$ ) for the lpr/lpr mice.

Renal histology. At 6 and $12 \mathrm{wk}$, control MRL (+/+) kidneys showed no evidence of pathology. At 18 and 22 wk, a mild mesangioproliferative glomerulonephritis without evidence of crescents, necrosis, sclerosis, or interstitial nephritis was observed. In contrast, the MRL lpr/lpr mice developed a mild increase in mesangial hypercellularity as early as $6 \mathrm{wk}$, which evolved into a diffuse, moderate mesangioproliferative glomerulonephritis by age $12 \mathrm{wk}$. Enlarged, reactive parietal epithelial cells were observed but there were no crescents. There was no evidence of interstitial nephritis. By age $18 \mathrm{wk}$, the lpr/lpr mice developed a diffuse, proliferative, necrotizing glomerulonephritis with crescents involving at least $50 \%$ of glomeruli and a moderate interstitial nephritis. By age $22 \mathrm{wk}$, virtually all glomeruli displayed crescent formation with periglomerular fibrosis and worsening interstitial nephritis (Table II). Scattered sclerosed glomeruli were observed.

Immunohistology with F4/80 antibody. Control (+/+) and experimental (lpr/lpr) kidneys were labeled for the presence of macrophages at 6 and $18 \mathrm{wk}$ of age. Control kidneys at $6 \mathrm{wk}$ had virtually no glomerular macrophages and a small number of resident, interstitial macrophages (Table II). Aged control mice showed a mild glomerular infiltration with macrophages and an insignificant increase in interstitial macrophages. In contrast, lpr/lpr mice displayed increased glomerular macrophages at $6 \mathrm{wk}$ and a marked increase in both glomerular and interstitial macrophages by 18 wk (Fig. 1 and Table II). At this time point, the interstitial infiltrate was diffusely peritubular, confined to the cortex, and not associated with tubular necrosis.

Expression of $m R N A$ in kidneys and other organs by Northern blot analysis. As early as 12 wk there was a slight, then progressive, increase in expression of both $\mathrm{C} 3$ and $\mathrm{C} 4$ mRNA in kidneys of the lpr/lpr strain; in the control MRL $+/+$ strain, there was a small, but definite increase in C3 and C4 mRNA with advancing age (Fig. 2). Both C2 and factor B mRNA are constitutively expressed in the kidneys in young animals of both MRL strains. A clear progressive increase in C2 mRNA during the development of glomerulonephritis was seen in the lpr/lpr strain, with only a minimal change noted in the $+/+$ animal. Factor B mRNA is expressed in the murine kidney as a doublet (reference 17 and Fig. 2), the smaller of the

Table II. Renal Histology in the MRL Strains

\begin{tabular}{|c|c|c|c|c|c|c|c|c|}
\hline & \multicolumn{4}{|c|}{$\operatorname{MRL}(+/+)$} & \multicolumn{4}{|c|}{ MRL (lpr/lpr) } \\
\hline Age (wk) & 6 & 12 & 18 & 22 & 6 & 12 & 18 & 22 \\
\hline Glomerulonephritis* & - & - & + & + & + & ++ & ++++ & ++++ \\
\hline Glomerular sclerosis* & - & - & - & + & - & - & ++ & ++ \\
\hline Interstitial inflammation* & - & - & - & - & + & ++ & +++ & ++++ \\
\hline \multicolumn{9}{|l|}{ F4/80 Stain } \\
\hline Glomerular macrophages ${ }^{\ddagger}($ mean $\pm \mathrm{SE})$ & $0.1 \pm 0.1$ & ND & ND & 0 & $2.3 \pm 0.7$ & ND & $12.0 \pm 1.5$ & ND \\
\hline Interstitial macrophages ${ }^{\S}($ mean $\pm S E)$ & $0.3 \pm 0.1$ & ND & ND & $0.9 \pm 0.4$ & $0.8 \pm 0.2$ & ND & $29.0 \pm 2.5$ & ND \\
\hline
\end{tabular}

ND, not done. * Description of scoring system is given in Methods. ${ }^{\ddagger}$ Macrophages (F4/80 positive)/glomerulus (all glomeruli in a section [10-20] were counted). ${ }^{\S}$ Macrophages (F4/80 positive)/100 tubule cells. 


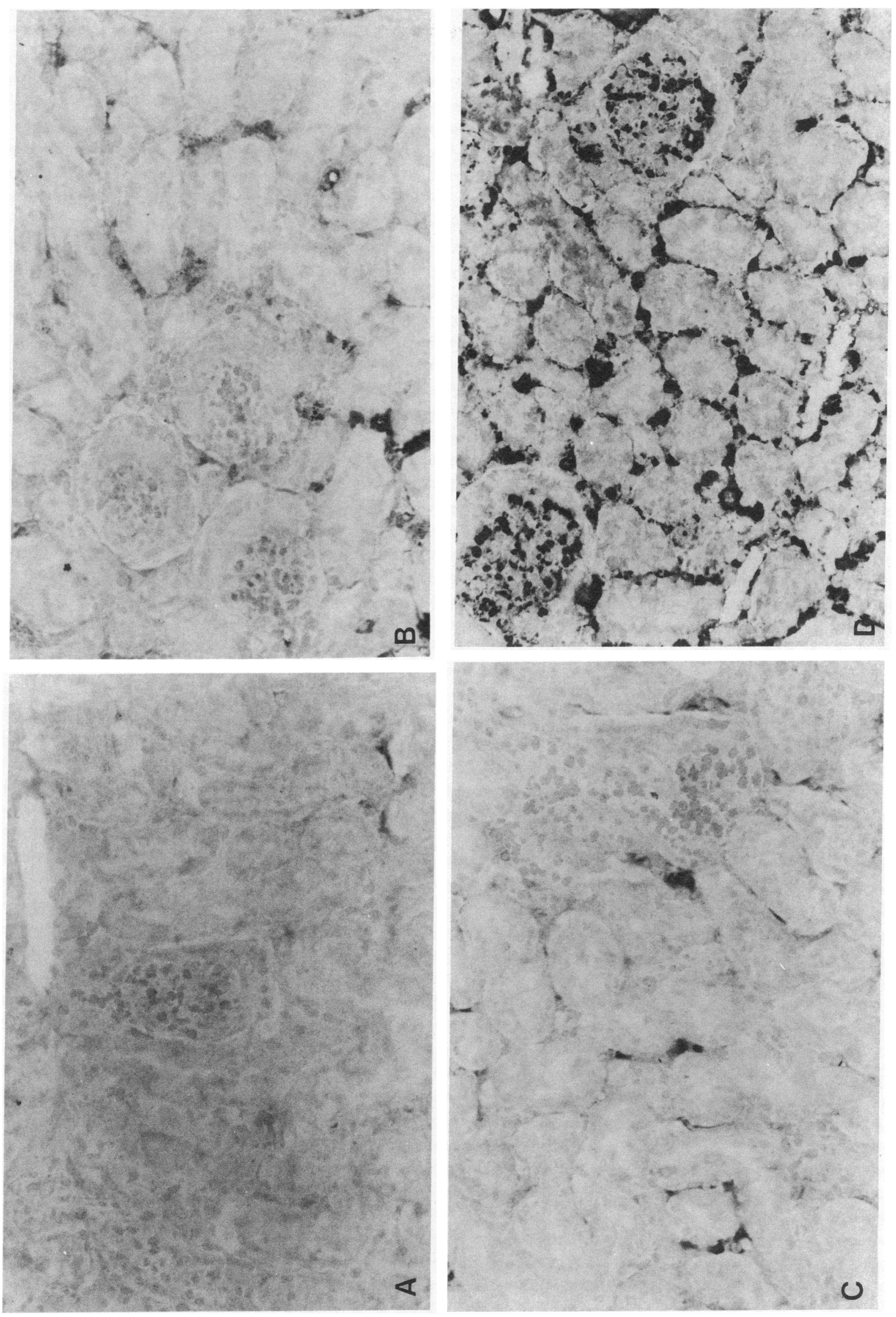

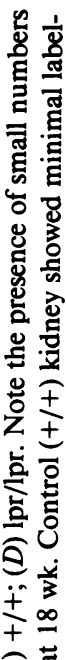
(을 它 $\infty$ 这音 흘 ธิ ․ㅡㅇ $+\frac{10}{+2}$ 동 造 के 훙 递 递 $\sum$

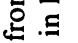
危 8 远 흘

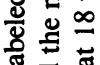
元 品灵 语

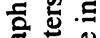
鴊 융.. 范 웅

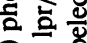
के 论 可焉 言. 용 文 $3+\frac{2}{3}$

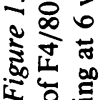


$\mathrm{C}_{4}$

$28 s^{-}$

$18 s-$
$\mathrm{C}_{3}$

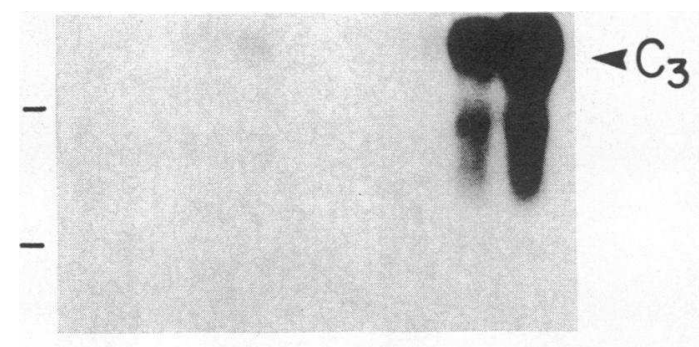

Factor B

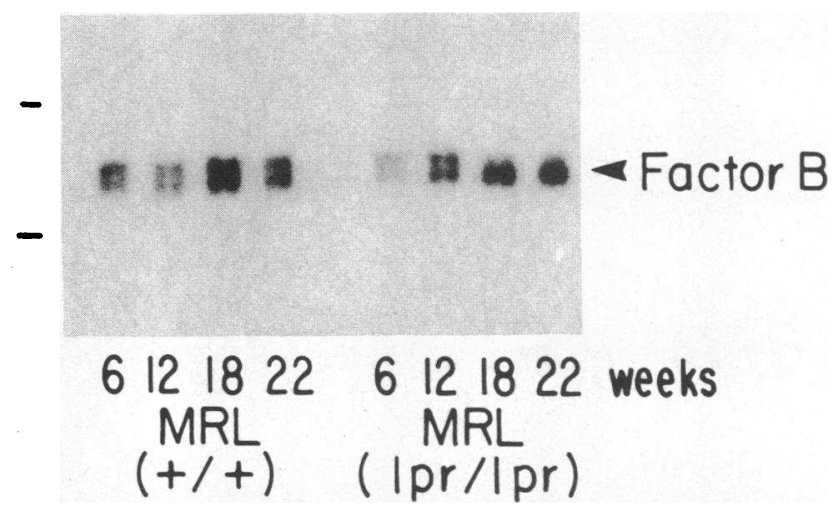

from each strain blotted and probed on replicate (three to four times) Northern analyses. Both by ethidium stain and actin mRNA content, there were no significant differences in amount of RNA loaded in each lane.

increase in each band is noted as the mice age. However, in the MRL lpr/lpr strain there is a significant and consistent increase in concentration of the lower band, while the upper
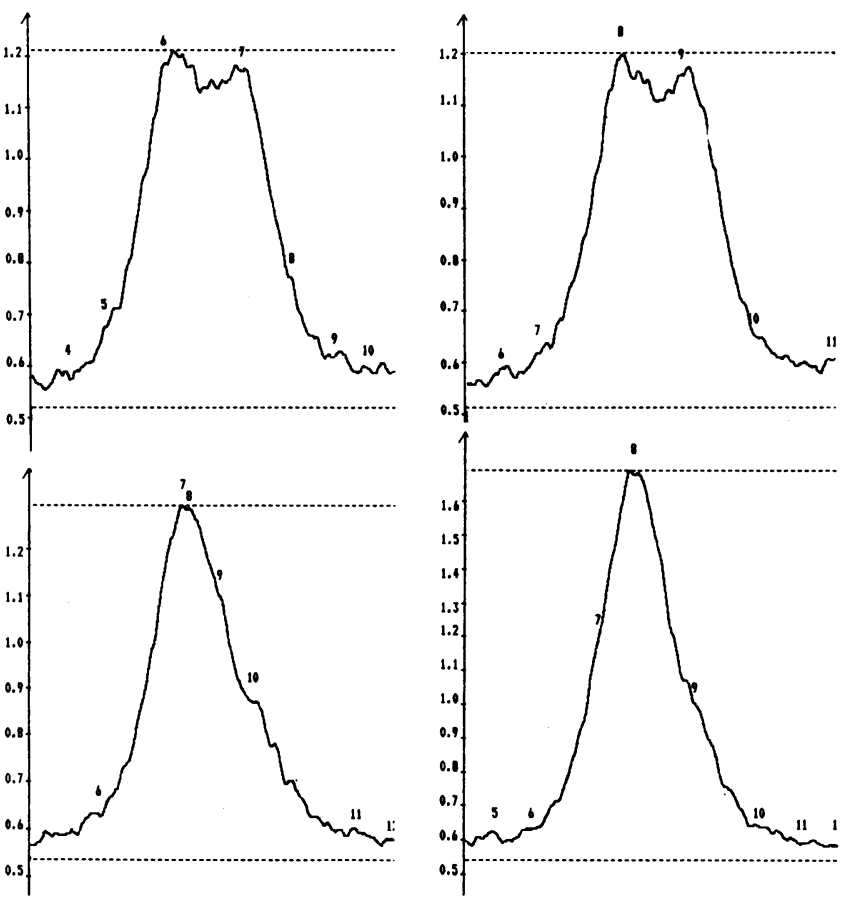

Figure 3. Tracing of laser densitometry of factor B mRNA in the kidney of the MRL $+/+$ and MRL lpr/lpr strain at ages $6,12,18$, and 22 wk (left to right). $10 \mu \mathrm{g}$ of RNA was loaded in each lane. Upper tracings from $(+/+)$ and lower tracings from (lpr/lpr). 
band decreases. It was not possible to accurately separate the bands for scintillation spectrometry, but laser densitometry clearly showed the presence of the double band, a twofold increase of the lower band and a $>80 \%$ fold decrease of the upper band with advancing age in the lpr/lpr strain (Figs. 2 and 3 ). Of all the other organs examined, only the intestine displays the double-banded factor B mRNA.

Synthetic oligomers homologous to $\mathrm{C} 4$ and Slp sequence were used to determine whether the Slp sequence of the $\mathrm{C4}$ gene was expressed in the kidney of this mouse strain. Only the sequence homologous to $\mathrm{C} 4$ hybridized to kidney mRNA at 18 and $22 \mathrm{wk}$ in the $\mathrm{lpr} / \mathrm{lpr}$ strain. No hybridization to kidney mRNA was observed with the Slp oligomer, but a strong signal was obtained when, for a control, a plasmid containing the Slp cDNA was probed with the Slp specific oligonucleotide (results not shown).

The expression of complement genes in other organs of the $+/+$ and lpr/lpr strain was estimated at 18 wk by Northern blot analysis as shown in Fig. 4. For liver, the source of plasma complement, the mRNA content of $\mathrm{C} 2, \mathrm{C} 3, \mathrm{C} 4$, and factor $\mathrm{B}$ in lpr/lpr was approximately twofold that of each in the $+/+$ strain (Fig. 4). There were no marked differences between the two strains in expression of these mRNA species in the spleen. However, a comparison of lung, heart and intestine in the two strains revealed substantially more $\mathrm{mRNA}$ in the lpr/lpr than in the $+/+$ strain at 18 wk.

Loading of the gels for Northern blotting was initially estimated by comparing ethidium bromide staining of the $28 \mathrm{~S}$ and 18S RNA bands. The chicken $\alpha$-actin cDNA probe which cross-hybridizes with both $\beta$ and $\gamma$-actin was used to more precisely estimate comparability of the data. Actin mRNA concentrations varied among the different organs, however, similar amounts were present for each organ in comparing the two mouse strains (Fig. 5).

Protein synthesis in kidney. Mice ages 6 and 18 wk of the congenic strains were used to study the biosynthesis of factor B and $\mathrm{C} 3$. Tissues were cultured for $1 \mathrm{~h}$ after an initial 20-min labeling period. Only the kidney specimens derived from the 18-wk old lpr/lpr strain synthesized significant amounts of C3 and factor B protein (Fig. 6). The majority of labeled C3 protein was expressed as pro-C3 with trace amounts of native $\mathrm{C3}$ detectable, as expected, in the intracellular compartment.

\section{Discussion}

We have demonstrated a progressive increase in mRNA corresponding to the complement genes $\mathrm{C} 3, \mathrm{C} 4, \mathrm{C} 2$, and factor $\mathrm{B}$ in the kidney of the MRL lpr/lpr mouse strain coincident with the development of glomerulonephritis and interstitial nephritis. This mRNA is translated, since kidney organ cultures derived from mice with glomerulonephritis manifested increased biosynthesis of $\mathrm{C} 3$ and factor B protein. This is the first demonstration of local regulation of complement genes and in situ synthesis of complement protein in an organ affected by a naturally evolving autoimmune disease. Similar increases in concentration of mRNA of these complement components in other organs that manifest autoimmune arteritis were observed, but there was little change in $\mathrm{C} 3, \mathrm{C} 4, \mathrm{C} 2$, and factor B mRNA in liver, although liver is the source of plasma complement proteins. These marked differences in ex-

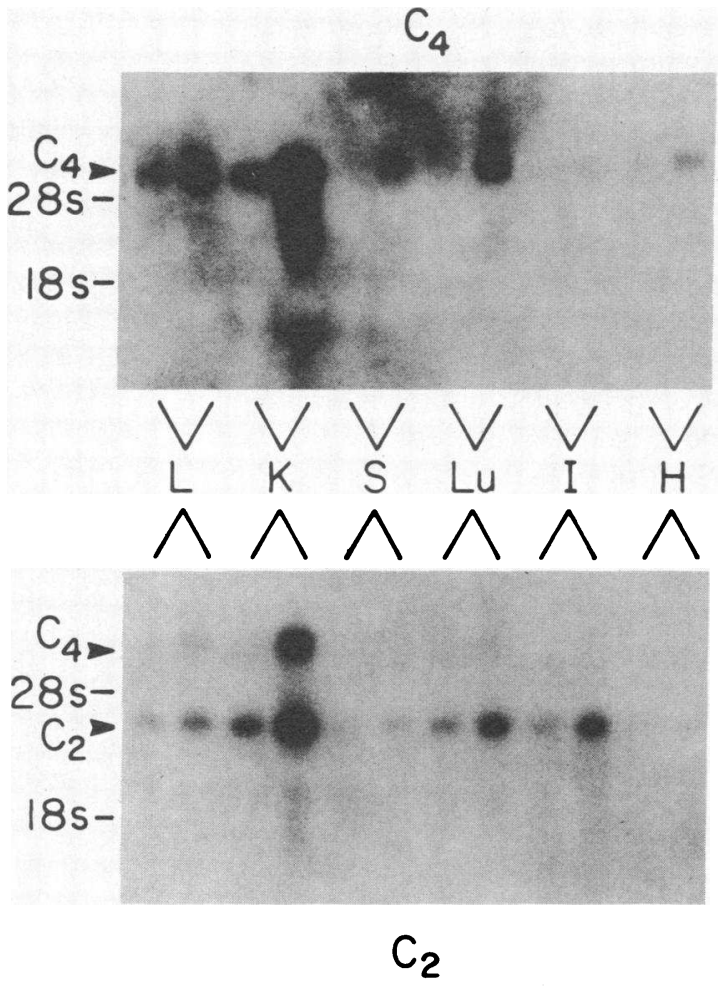

Figure 4. Northern blot analysis of C4, C3, C2, and factor B mRNA in organs of MRL $+/+$ and MRL lpr/lpr at 18 wk of age. $10 \mu \mathrm{g}$ of total RNA was loaded in each lane except for liver where $5 \mu \mathrm{g} /$ lane of RNA was loaded in each. $L$, liver; $K$, kidney; $S$, spleen; $L u$, lung;

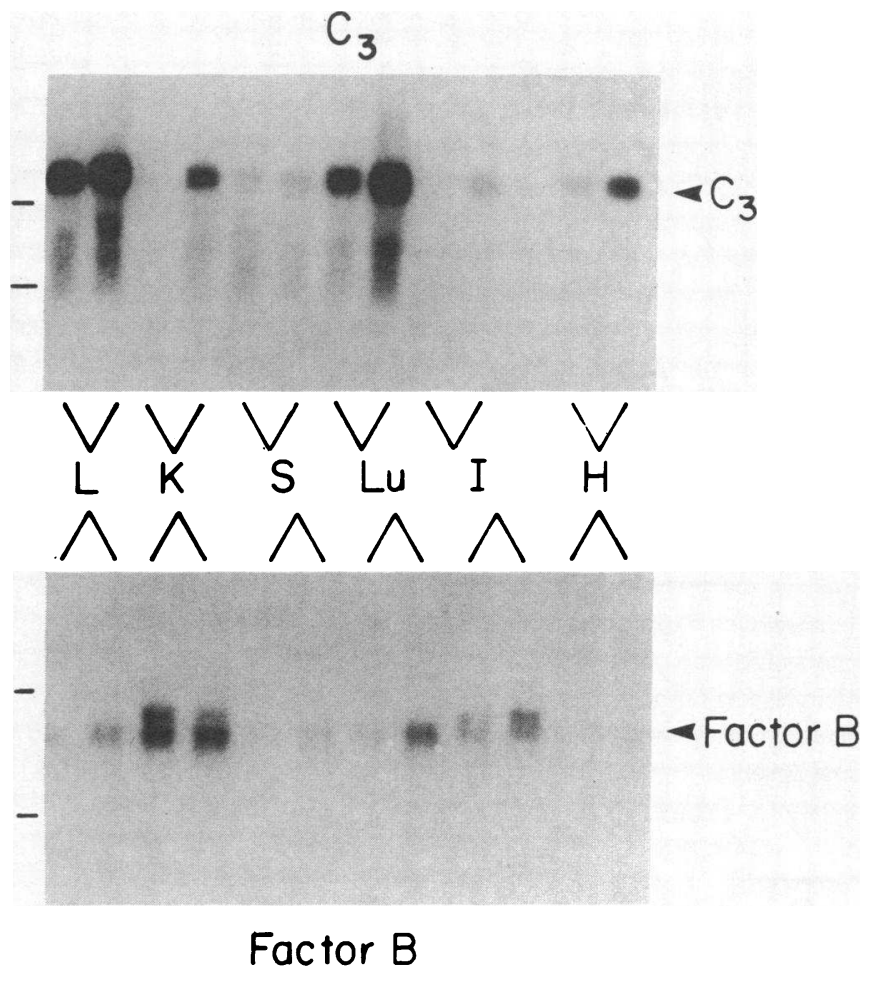

$I$, intestine; $H$, heart. First sample of each pair from $(+/+)$ and second from (lpr/lpr) organs. This experiment is one of four separate Northern blots performed on each of three sets of animals. 


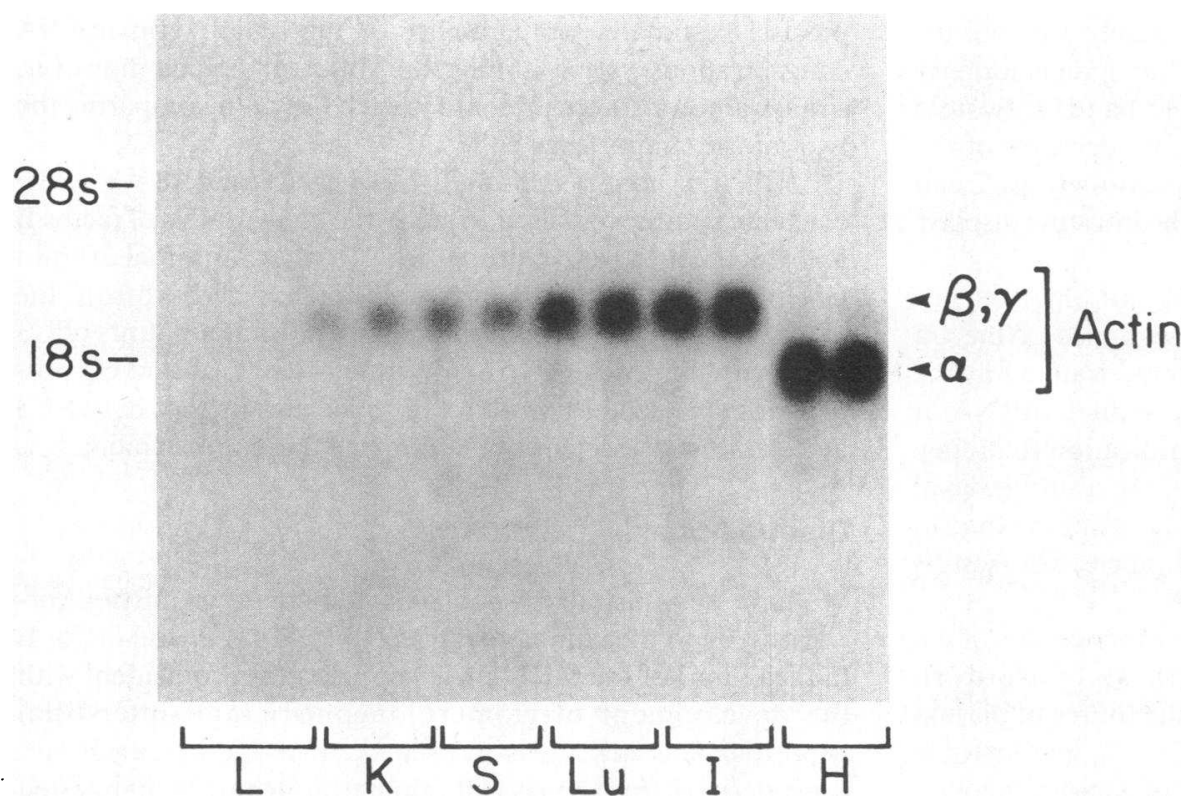

Figure 5. Northern blot analysis of actin mRNA (probed with chicken $\alpha$-actin cDNA) in organs of MRL $+/+$ and MRL $\mathrm{lpr} / \mathrm{lpr}$ mice strains at $18 \mathrm{wk}$ of age. All lanes loaded with $10 \mu \mathrm{g}$ per lane except for liver with $5 \mu \mathrm{g}$ per lane. $L$, liver; $K$, kidney; $S$, spleen; $L u$, lung; $I$, intestine; $H$, heart. Left lane of each pair $(+/+)$ and right (lpr/lpr). pression of complement mRNA at local sites of inflammation suggest that local complement production may play a role in the pathogenesis of the autoimmune pathology and that local regulatory factors modulate this effect.

The identification of two forms of factor B mRNA in kidney and intestine, but not in other organs, is an instance of tissue specificity in expression of this complement gene. Only

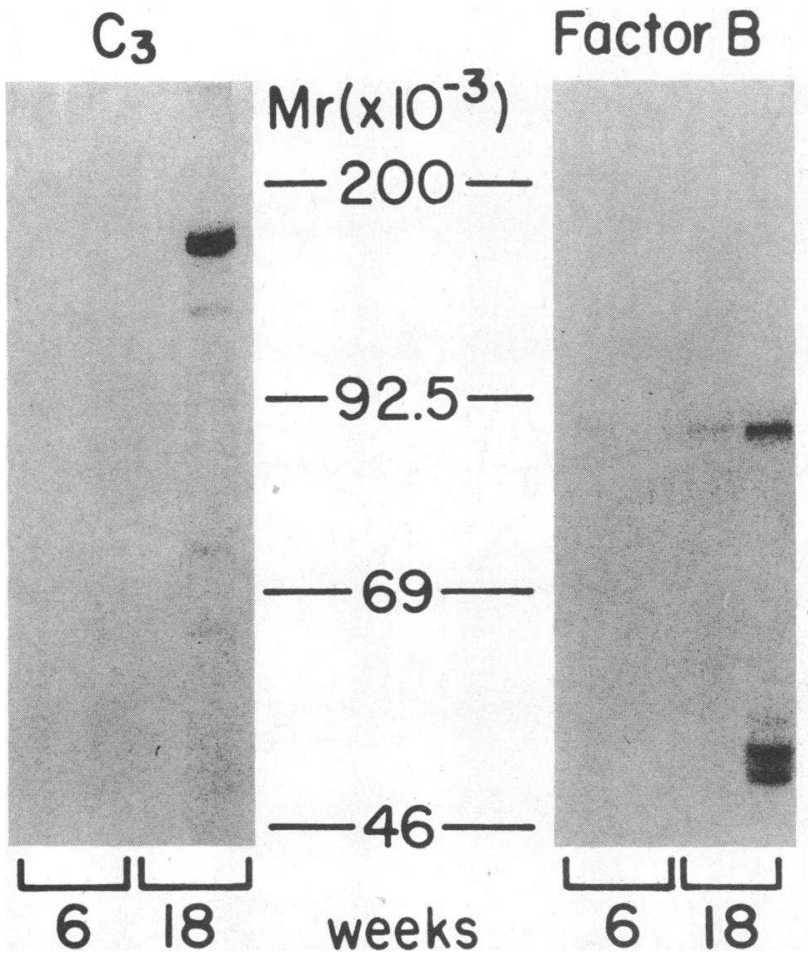

Figure 6. SDS-PAGE of immunoprecipitated $\left[{ }^{35}\right.$ S $]$ methionine 1-h pulse-labeled $\mathrm{C} 3$ and factor $\mathrm{B}$ from kidney organ culture lysates of 6and 18-wk old MRL +/+ (left lane in each pair) and MRL lpr/lpr mice (right lane in each pair). Molecular mass markers (D) are indicated. the smaller of the two factor B mRNA species was upregulated, coincidental with advancing kidney disease, while the larger form decreased by $>80 \%$. A similar increase of the smaller mRNA species in mouse kidney has been induced by intraperitoneal injection of endotoxin (unpublished results). Other genes expressing different forms of mRNA in a tissue specific manner have been described. One example of this is the expression of $\alpha$-amylase in mouse liver and salivary gland. In this instance differences in expression of mRNA have been attributed to variation in $5^{\prime}$ untranslated regions which were thought to arise by either differential transcription and/or processing of the mRNA (27).

Although increases in complement-specific mRNA and protein synthesis during the evolution of nephritis correlated with increased numbers of macrophages, attribution of the observed changes to a specific cell type must remain speculative. That is, it is possible that the different factor B mRNA species are derived from different cells within the same organ. Indeed, such a mechanism has recently been described for expression of the human $\alpha-1$ proteinase inhibitor gene. Macrophages and hepatocytes express $\alpha-1$ proteinase inhibitor, but two mRNA species are found in macrophages (28), both of which are larger than the hepatocellular $\alpha$-1 PI mRNA. In each cell different promoter sequences have been identified. An alternative splicing mechanism apparently accounts for the two forms of mRNA found in the macrophage (29). In immune complex glomerulonephritis, hypercellularity can be attributed to macrophage infiltration and to proliferation of intrinsic glomerular cells, particularly mesangial cells. Macrophages (30) and fibroblasts (Y. Katz, F. S. Cole, R. C. Strunk, unpublished results) synthesize factor B in tissue culture, however, both express only the smaller of the two factor B mRNA species. Further studies using in situ hybridization or isolated kidney cell preparations will be needed to determine whether the two factor B mRNA species are derived from a single or multiple cell types. Finally, the two factor B mRNA species expressed in intestine are also modulated during progression of SLE with a pattern qualitatively distinct from that observed in kidney. This observation suggests either different cells express 
factor B in kidney and intestine or a more complex mechanism of regulation of the two forms of $B$ mRNA must exist.

The F4/80 membrane antigen is a specific marker of mouse macrophages (19). We have used monoclonal antibody to this antigen to demonstrate that in this mouse model of immune complex glomerulonephritis, macrophages infiltrate the glomerulus and the interstitium, where they are the predominant inflammatory cell. Macrophages produce complement locally and monokines may act on adjacent cells. The regulation of complement biosynthesis by the monokines IL-1 and TNF in mouse and human hepatocytes has been well documented. The effect of these monokines is exerted at a pretranslational level, selectively upregulating factor $\mathrm{B}, \mathrm{C} 3$ and C4 but not C2 (31-33). However, in vivo administration of rIL-1 increases renal concentrations of C2, C3 and factor B mRNA (17). The distinct pattern in this SLE model of increased mRNA of all the complement components we studied suggests a common mediator of this upregulation. In vitro studies with recombinant IFN- $\gamma$ have shown that it enhances the mRNA and synthesis of C2, B, C3 and C4 in mononuclear phagocytes (33). In this regard, it is of interest that in vivo administration of IFN $\gamma$ aggravates, while ablation of $\mathrm{T}$ lymphocyte function ameliorates, progression of murine SLE $(34,35)$.

In acute immune complex kidney disease, circulating immune complexes are deposited within the subendothelial and mesangial regions of the glomerulus. Serum complement concentration decreases and local activation of the complement cascade occurs (36). Activation of complement leads to recruitment of other inflammatory cells and enhanced opsonization of immune complexes. In addition, components of the classical complement pathway inhibit immune complex deposition and enhance solubilization of immune complexes (37, 38). Hence, local production of complement may significantly modify the evolution of immune nephritis. Our studies demonstrate that increased local production of complement also occurs in the kidney coincident with the development of glomerulonephritis and interstitial nephritis. Thus, in situ renal synthesis of complement proteins may exacerbate or protect against immune complex mediated tissue injury.

\section{Acknowledgments}

We thank Ms. Barbara Pellerito for assistance in preparation of the manuscript.

This work was supported in part by grants AI24836, AI24739, DK36277, and HL37591 from the U. S. Public Health Service and a grant from the Samuel Jared Kushnick Foundation.

\section{References}

1. Andrews, B. S., R. A. Eisenberg, A. N. Theofilopoulos, S. Izui, C. B. Wilson, P. J. McConahey, E. D. Murphy, J. B. Roths, and F. J. Dixon. 1978. Spontaneous murine lupus-like syndromes: clinical and immunopathological manifestations in several strains. J. Exp. Med. 148:1198-1215.

2. Theofilopoulos, A. N., and F. J. Dixon. 1985. Murine model of systemic lupus erythematosus. Adv. Immunol. 37:269-390.

3. Weston, K. M., E. T. H. Yeh, and M.-S. Sy. 1987. Autoreactivity accelerates the development of autoimmunity and lymphoproliferation in MRL/Mp-lpr/lpr mice. J. Immunol. 139:734-742.

4. Seaman, W. E., D. Wofsy, J. S. Greenspan, and J. A. Ledbetter. 1983. Treatment of autoimmune MRL/lpr mice with monoclonal an- tibody to Thy-1.2: a single injection has sustained effects on lymphoproliferation and renal disease. J. Immunol. 130:1713-1718.

5. Steinberg, A. D., J. B. Roths, E. D. Murphy, R. T. Steinberg, and E. S. Raveche. 1980. Effects of thymectomy or androgen administration upon the auto-immune disease of MRL/MP-lpr/lpr mice. J. Immunol. 125:871-873.

6. Theofilopoulos, A. N. 1982. Role of the thymus in murine lupus and cellular transfer of the disease. Arthritis Rheum. 25:726-733.

7. Mountz, J. D., H. R. Smith, R. L. Wilder, J. Patton Reeves, and A. D. Steinberg. 1987. CS-A therapy in MRL-lpr/lpr mice: amelioration of immunopathology despite auto-antibody production. $\mathrm{J}$. Immunol. 138:157-163.

8. Couser, W. G. 1985. Mechanisms of glomerular injury in immune complex disease. Kidney Int. 28:569-583.

9. Schreiner, G. F., R. S. Cotran, U. Pardo, and E. R. Unanue. 1978. A mononuclear cell component in experimental immunological glomerulonephritis. J. Exp. Med. 147:369-384.

10. Holdsworth, S. R., T. J. Neale, and C. B. Wilson. 1981. Abrogation of macrophage-dependent injury in experimental glomerulonephritis in the rabbit. J. Clin. Invest. 68:686-698.

11. Kimura, M., M. Nagase, A. Hishida, and N. Honda. 1987. Intramesangial passage of mononuclear phagocytes in murine lupus glomerulonephritis. Am. J. Pathol. 127:149-156.

12. Schreiner, G. F., J. M. Kiely, R. S. Cotran, and E. R. Unanue. 1981. Characterization of resident glomerular cells in the rat expressing Ia determinants and manifesting genetically restricted interactions with lymphocytes. J. Clin. Invest. 68:920-931.

13. Boyce, N. W., and S. R. Holdsworth. 1986. Quantitation of the intrarenal uptake of immunoglobulin aggregates by macrophages in diffuse proliferative glomerulonephritis. Clin. Exp. Immunol. 64:638645 .

14. Stork, J. E., and M. J. Dunn. 1985. Hemodynamic roles of thromboxane A2 and prostaglandin E2 in glomerulonephritis. $J$. Pharmacol. Exp. Ther. 233:672-678.

15. Wiggins, R. C., A. Glatfelter, and J. Brukman. 1985. Procoagulant activity in glomeruli and urine of rabbits with nephrotoxic nephritis. Lab. Invest. 53:156-165.

16. Alpert, S. E., H. S. Auerbach, F. S. Cole, and H. R. Colten. 1983. Macrophage maturation differences in complement secretion by marrow, monocyte, and tissue macrophages detected with an improved hemolytic plaque assay. J. Immunol. 130:102-107.

17. Falus, A., H. U. Beuscher, H. S. Auerbach, and H. R. Colten. 1987. Constitutive and IL-1 regulated murine complement gene expression is strain and tissue specific. J. Immunol. 138:856-860.

18. Ramadori, G., J. D. Sipe, and H. R. Colten. 1985. Expression and regulation of the murine serum amyloid A (SAA) gene in extrahepatic sites. J. Immunol. 135:3645-3647.

19. Lee, S. H., P. M. Starkey, and S. Gordon. 1985. Quantitative analysis of total macrophage content in adult mouse tissues: Immunochemical studies with monoclonal antibody F4/80. J. Exp. Med. 161:475-489.

20. Schreiner, G., Cotran, R., Pardo, V., and Unanue, E. R. 1978. A mononuclear cell component in experimental immunological glomerulonephritis. J. Exp. Med. 147:369-384.

21. Chirgwin, T. M., A. E. Przybyla, R. J. MacDonald, and W. J. Rutter. 1979. Isolation of biologically active ribonucleic acid from sources enriched in ribonuclease. Biochemistry. 18:5294-5299.

22. Thomas, P. 1980. Hybridization of denatured RNA and small DNA fragments transferred to nitrocellulose. Proc. Natl. Acad. Sci. USA. 77:5201-5205.

23. Falus, A., E. K. Wakeland, T. J. McConnell, J. Gitlin, A. S. Whitehead, and H. R. Colten. 1987. DNA polymorphism of MHC III genes in inbred and wild mouse strains. Immunogenetics. 25:290-298.

24. Nonaka, M., K. Nakayama, Y. D. Yuel, and M. Takahashi. 1985. Complete nucleotide and derived amino-acid sequences of the fourth component of mouse complement (C4). J. Biol. Chem. 260:10936-10943.

25. Schwartz, R. J., J. A. Haron, K. N. Rothblum, and A. Dugaic- 
zyk. 1980. Regulation of muscle differentiation: cloning of sequences from alpha-actin messenger ribonucleic acid. Biochemistry. 19:58835890.

26. Sackstein, R., H. R. Colten, and D. W. Woods. 1983. Phylogenetic conservation of a class III major histocompatibility complex antigen, factor $B$ : isolation and nucleotide sequencing of mouse factor B cDNA clones. J. Biol. Chem. 258:14693-14697.

27. Young, R. A., D. Hagenbuchle, and U. Schibler. 1981. A single mouse $\alpha$-amylase gene specifies two different tissue-specific mRNAs. Cell. 23:451-458.

28. Perlmutter, D. H., R. M. Kay, F. S. Cole, T. H. Rossing, D. Van Thiel, and H. R. Colten. 1985. The cellular defect in alpha 1 proteinase inhibitor $\left(\mathrm{alpha}_{1} \mathrm{PI}\right)$ deficiency is expressed in xenopus oocytes injected with human liver RNA. Proc. Natl. Acad. Sci. USA. 82:6918-6921.

29. Perlino, E., R. Cortese, and G. Ciliberto. 1987. The human $\alpha_{1}$-antitrypsin gene is transcribed from two different promoters in macrophages and hepatocytes. EMBO (Eur. Mol. Biol. Organ.) J. 6:2767-2771.

30. Perlmutter, D. H., and H. R. Colten. 1986. Molecular immunobiology of complement biosynthesis: a model of single-cell control of effector-inhibitor balance. Annu. Rev. Immunol. 4:231-251.

31. Perlmutter, D. H., G. Goldberger, C. A. Dinarello, S. B. Mizel, and H. R. Colten. 1986. Regulation of class III major histocompatibility complex gene products by interleukin 1. Science (Wash. DC). 232:850-852.
32. Perlmutter, D. H., C. A. Dinarello, P. I. Punsal, and H. R. Colten. 1986. Cachectin/tumor necrosis factor regulates hepatic acute-phase gene expression. J. Clin. Invest. 78:1349-1354.

33. Strunk, R. C., F. S. Cole, D. H. Perlmutter, and H. R. Colten. 1985. $\gamma$-Interferon increases expression of class III complement genes $\mathrm{C} 2$ and factor $\mathrm{B}$ in human monocytes and in murine fibroblasts transfected with human C2 and factor B genes. J. Biol. Chem. 260:1528015285.

34. Adam, C., Y. Thoua, P. Ronco, P. Verroust, M. Tovey, and L. Morel-Maroger. 1980. The effect of exogenous interferon: acceleration of autoimmune and renal diseases in (NZB/W) F1 mice. Clin. Exp. Immunol. 40:373-382.

35. Heremans, H., A. Billiau, A. Colombatti, J. Hilgers, and P. DeSomer. 1978. Interferon treatment of NZB mice: accelerated progression of autoimmune disease. Infect. Immun. 21:925-930.

36. Wener, M. H., and M. Mannik. 1986. Mechanisms of immune deposit formation in renal glomeruli. Springer Semin. Immunopathol. 9:219-235.

37. Miller, G. W., and V. Nussenzweig. 1975. A new complement function: solubilization of antigen-antibody aggregates. Proc. Natl. Acad. Sci. USA. 72:418-422.

38. Schifferli, J. A., Y. C. Ng, and D.-K. Peters. 1986. The role of complement and its receptor in the elimination of immune complexes. N. Engl. J. Med. 315:488-495. 